\title{
Communism, Post-Communism, and Democracy
}

\author{
Jeffrey C. Isaac
}

\begin{abstract}
une 1917. A world is at war. Empires-in Europe, Eurasia, Asia, the Middle East and North Africa$\bigcup$ are crumbling.
\end{abstract}

Rosa Luxemburg, the Polish-German revolutionary Marxist, had anticipated the destruction in her prescient "Junius Pamphlet": "This world war is a regression into barbarism. The triumph of imperialism leads to the annihilation of civilization. At first, this happens sporadically for the duration of a modern war, but then when the period of unlimited wars begins it progresses toward its inevitable consequences. Today, we face the choice exactly as Friedrich Engels foresaw it a generation ago: either the triumph of imperialism and the collapse of all civilization as in ancient Rome, depopulation, desolation, degenerationa great cemetery. Or the victory of socialism, that means the conscious active struggle of the international proletariat against imperialism and its method of war. This is a dilemma of world history, an either/or; the scales are wavering before the decision of the class-conscious proletariat. The future of civilization and humanity depends on whether or not the proletariat resolves manfully to throw its revolutionary broadsword into the scales. In this war imperialism has won. Its bloody sword of genocide has brutally tilted the scale toward the abyss of misery. The only compensation for all the misery and all the shame would be if we learn from the war how the proletariat can seize mastery of its own destiny and escape the role of the lackey to the ruling classes."

Luxemburg wrote these words in 1915, from a German prison cell. Within four years the cataclysm unfolded, though not quite as she imagined, in a dialectical synergy of revolutionary socialism and barbarism; and she lay dead, assassinated by right-wing paramilitary forces, the Freikorps, allied with Friedrich Ebert, the first President of the recently installed Weimar Republic, who was, ironically, a Social Democrat.

At the core of this cataclysm was the Russian Revolution of 1917, inaugurated by the overthrow of Czar Nicholas II and the creation of a Provisional Government in February, and capped by the seizure of power in Petrograd by the Bolsheviks, under the leadership of Lenin, in October, leading eventually to the establishment of the Soviet Union (Union of Soviet Socialist Republics). The Russian Revolution did much more than lay the foundations for a powerful new Soviet state that would play a fundamental role in the politics of the century to come. It also set off waves of radicalism and reaction that would shake the foundations of European politics leading, in a complicated way to be sure, to the rise of fascism, the emergence of Stalinist totalitarianism in Russia and Nazi totalitarianism in Germany, and eventually a Second World War that for many simply meant a continuation of the first one by even deadlier means.

In 1941 Henry Luce, the publisher of Time magazine, famously labeled the 20th century "the American Century." At the time, this was wishful thinking-and hortatory advocacy for a globalist foreign policy — as much as it was sharp prognosis. For from 1917-1945 world politics was shaped by a three-cornered conflict between fascism, communism, and liberal democracy, and in 1941 it was entirely unclear which ideology would prevail, and just as unclear whether the US would even enter the Second World War. (Let us not forget the "America First" movement that lobbied hard for nonintervention in part out of sympathy with fascism. The movement failed. Who would have guessed that its ideological heir would one day become the $45^{\text {th }}$ President of the US?) And after 1945, world politics was shaped by the "bipolar" conflict between US and USSR that defined the Cold War. The century perhaps became "American" after 1989, with the fall of the Berlin Wall, the ascendancy of the US as the world's only "superpower," and the announced "end of history." But eleven years is not a very long time, and in truth it took less than a year or two for "history" to reassert itself with a vengeance.

For the past century, no aspect of US political sciencewhether IR or comparative politics or political theory or even the study of American politics-has been untouched by the intellectual and political challenges presented by the rise of Communism in Russia in 1917. The behavioral revolution of post-World War II American political science was powerfully shaped by the contrast between "pluralist democracy" and "totalitarianism," with the latter 
considered exemplified by the USSR. All of the most influential "democratic theorists" of this period-Robert Dahl, Seymour Martin Lipset, Giovanni Sartori, and so many others - wrote with this contrast in mind. Much of the scholarship on development, modernization, and even political party development, was similarly shaped by the challenges presented by Communism.

But the impact of the Russian Revolution on political science was felt long before the beginning of the Cold War.

Indeed, it is interesting to revisit the coverage of the Revolution and its immediate aftermath in the still-veryyoung American Political Science Review which, at the time of the Revolution, was merely eleven years old, even younger than Perspectives is today. The May 1918 issue contained a piece by Simon Litman, "Revolutionary Russia," that was clearly written within weeks of the Bolshevik seizure of power. Litman reflected a widespread consensus among American liberals, including liberal academics, about the "progressive" character of the revolution, which threw off "the yoke of despotism": "The present power of the socialists in general and of the Bolsheviki in particular may be attributed to the fact that under the stress of the war the Russian machinery of production and distribution collapsed ... Little wonder that, after the overthrow of autocracy, the poor and the suffering, the cold and the hungry, were willing to accept any regime that promised them thereof. .. the mass of the people accepted the leadership of those who spoke most loudly, acted most vigorously and who promised them the greatest amount of prosperity and the quickest way to peace and leisure... "A year later, the journal ran a discussion, "Observations on Soviet Government," based on first-hand reporting by University of Illinois political scientist Russell M. Story. Story notes that "between March and November, 1917, the institutional basis of state power in Russia was radically altered" by the rise of the soviets. He also waxes eloquently about the democratic character of the Soviet Revolution: "For the first time the soviet caught the fancy and devotion of the masses ... Opportunity was offered for all voices that so desired to be heard ... Brickmaker spoke to brickmaker, textile worker to textile worker, store clerk to store clerk. The repressed and pent up grievances, beliefs, aspirations of tens of thousands found expression in words ... Moreover the verdict as to policy was never closed. It was always open to readjustment in accord with new and subsequent expressions of opinion. Delegates could be recalled at will." Story notes the weaknesses of the soviets as institutions, and also notes that "For the moment the party in power [the Bolsheviks-J.I.] may even resort to the suppression of minorities in the soviet-but there is no reason to believe such suppression has been serious enough to menace the existence or popularity of the institution." And he concludes that "The real test of soviet government will be whether or not it works. .."
The May 1920 issue of the journal includes an interesting piece by a Russian émigré scholar, Baron S. A. (Sergel Aleksandrovich) Korff, on "The Future Russian Constitution as Seen by Liberals." Korff harshly criticizes the Bolsheviks and their conception of "dictatorship of the proletariat." But even this displaced Russian liberal sounds a note of hopefulness, concluding that while "the future fathers of the new Russian constitution" face many challenges "we all accept democracy as axiomatic." Needless to say, his liberal democratic constitutionalist hopes came to naught.

Perhaps the most interesting APSR piece on the Russian Revolution during this period was "Soviet Government in Russia," by E.A. Ross and Selig Perlman, published in the May 1920 issue. Ross and Pearlman were both major figures in the development of American social science at the turn of the $20^{\text {th }}$ century, and their article is an exceptionally judicious, scholarly-analytical account of the unfolding revolutionary dynamics in Russia. They note, for example, that while the Bolsheviks have sought to remove all opposition to them in the soviets, "it would ... seem legitimate to discuss the novel form of political organization exhibited in the soviet system on its own merits, disregarding as far as may be the peculiar uses to which the Bolshevist party has put the instrumentalities furnished by the new constitution." They carefully compare the soviet system of occupational representation with the system of parliamentary representation, delineating their competing logics, and noting strengths and weaknesses of each. They note that the weakness of parliamentarism in Russia has deep historical roots, and also that "the broad masses of the Russian people" have good reasons "for doubting the western forms of democracy." They do not hide their concern about Bolshevik authoritarianism nor their fascination with the unfolding developments, and indeed they strike a note of reasoned skepticism: "no one who cares anything for whatever scientific reputation he may possess will venture at this distance and at this time to say what actually is the working of Russia's political experiment."

By the end of the decade Josef Stalin had succeeded in eliminating all remaining rivals from the revolutionary leadership of 1917, establishing a dictatorial regime centered on the repression of all political and ideological opposition, the forced collectivization of agriculture, the creation of a vast system of carceral terror ("the Gulag"), and the promotion of a massive cult of personality. The Russian "political experiment" was thus brought to an end with the institution of a full-fledged totalitarian regime. In very broad strokes the rest of the history is known: the Hitler-Stalin Pact of 1939; the eventual entrance of the USSR in the Second World War after Hitler's 1941 invasion, and its decisive role in the defeat of the Axis powers; the post-WWII Soviet occupation of Eastern Europe, the creation of a set of satellite regimes through 
the Warsaw Pact, and the Cold War; the periodic upsurge of revolts against Soviet hegemony throughout Eastern Europe, and the glimmerings of dissent even within the USSR itself; the eventual crisis and dissolution of Communist regimes throughout Eastern Europe after 1989; and the declared end of the Soviet Union itself on December 26, 1991. We now inhabit a "post-communist" world. But not a "post-historical" one.

Ronald Suny's review essay, "The Left Side of History: The Embattled Pasts of Communism in the Twentieth Century," makes clear the importance of a long duree perspective on contemporary history: "A quarter century separates us from the last years of the USSR, and the postmortems on the legacy of actually existing socialisms continue to reflect on that central experience of the short twentieth century. How the twentieth century is understood, what meaning is given to the colossal struggle between Communism and Fascism and the resultant triumph —at least for a time-of liberalism, bourgeois democracy, and market capitalism, holds more than academic interest. The meanings that become dominant will inform politicians and journalists, teachers and policymakers, who will use their grasp of the past to plod through the present to acquire some predictability about the future." A central theme of the books that Suny reviews is that Europe, and indeed the entire world subject to European influence, was beset by "an international civil war from the beginning of the First World War to the end of the Second," and that the ideological contests of this period continue to reverberate into the present (Peter Caldwell's "The Collapse of the Weimar Republic," and our symposium on Aviezer Tucker's The Legacies of Totalitarianism: A Theoretical Framework, similarly underscore the long-term impact of the profound political crises and ideological conflicts of this period).

Given the importance of this history for politics and for political science, it seems appropriate to mark the centenary of the Russian Revolution by devoting a special issue to the theme of "Communism, Post-Communism, and Democracy."

We lead with Stephen Hanson's "The Evolution of Regimes: What Can Twenty-Five Years of Post-Soviet Change Teach Us?" Hanson proceeds by observing "how little scholarly common ground there is at present concerning the proper periodization of regime change in the region." Drawing on Weber, he develops an "evolutionary view of institutional change" and argues that it "helps to explain both the rise and fall of the Soviet Leninist regime, and the main features of the divergent political and economic outcomes in East-Central Europe and Eurasia over the first quartercentury since the end of communism." Hanson's piece is a major work of comparative historical inquiry. He acknowledges "the enduring power of communist and even precommunist institutional legacies in shaping postcommunist political outcomes," but also incorporates questions of geography, political timing, generational change and, of course, elite strategies of seeking power in an "often chaotic milieu in which collective action to support the creation of new forms of legitimate domination became extremely difficult." Together, he argues, these factors help explain why "for most of the first quarter-century after the collapse of Leninism in East-Central Europe and Eurasia, one could observe a sharp difference between the relatively successful institutionalization of essentially liberal democratic capitalism in East-Central Europe and the Baltic States, versus the hegemony of non-democratic, personalistic politics in the rest of the former Soviet Union."

The diverse trajectories of "post-communism" figure in many of this issue's contributions. Michael Bernhard et al.'s "Making Embedded Knowledge Transparent: How the V-Dem Dataset Opens New Vistas in Civil Society Research" extends the V-Dem research agenda of comparative democratization outlined in their June 2011 Perspectives article on "Conceptualizing and Measuring Democracy: A New Approach." Bernhard and his colleagues develop two new indices to measure "the strength of post-communist civil society" - the Core Civil Society Index and the Civil Society Participation Index. They proceed to suggest the power of the indices by demonstrating how they help to explain variation in post-communist outcomes: "what we see is a divide between those countries that were formerly part of the Soviet Bloc and those what were part of the Soviet Union. The former, when we control for their economic and political development, have had great success in building postcommunist civil societies. For the countries of the former Soviet Union, we can talk about a weak postcommunist civil society at least from the perspective of citizen and CSO [civil society organization] participation. Thus we conclude that there is no uniform postcommunist malaise when it comes to civil society, but a set of two strongly diverging trajectories." The sources of this divergence are also taken up in our Critical Dialogue between Lucan Way, author of Pluralism by Default: Weak Autocrats and the Rise of Competitive Politics, and Henry Hale, author of Patronal Politics: Eurasian Regime Dynamics in Comparative Perspective. Our symposium on Aviezer Tucker's The Legacies of Totalitarianism: A Theoretical Framework also deals with the path dependencies and diverse historical legacies associated with Leninism, and features commentaries by Michael Bernhard, András Bozóki, Valerie Bunce, Barbara Falk, and Vladimir Tismăneanu.

While the contributions noted above address a range of more specific historiographical and analytical questions, they all center on a single core theme-the links between communism and post-communism, and the varied and tenuous links between post-communism and democratization. Gulnaz Sharafutdinova and Karen Dawisha's "The Escape from Institution-Building in a Globalized World: Lessons from Russia," engages this question through an analysis of the emergence and functioning of the Russian "oligarchy" and its ties to international 
financial institutions. In "The Intellectual History of Postcommunism," Venelin Ganev raises questions about the limits of post-communist liberalism via a critical review of Michal Kopeček and Piotr Wcislik's anthology, Thinking Through Transition: Liberal Democracy, Authoritarian Pasts, and Intellectual History in East Central Europe After 1989.

If Ganev thinks that Central European liberals have become too arrogant for their own good, our symposium on Peter Krastev and Jon Van Til's The Hungarian Patient: Social Opposition to an Illiberal Democracy, features a range of commentators who argue that liberalism is currently under siege. These two pieces both discuss important books recently published by Central University Press that feature mostly Hungarian writers. Central European University, founded with a grant from the Soros Foundation in 1991, has been a very important institution dedicated to scholarship and teaching about democracy and democratization (indeed its first President and Rector was US political scientist Alfred Stepan, famous for his scholarship with Juan Linz on democratization, who served from 1993-1996). It has recently come under attack by Hungarian Prime Minister Viktor Orban and others connected to his Fidez party, whose explicit commitment to a nationalist "illiberal democracy" puts them at odds with an institution that is so clearly committed to transnationalism and liberal values (these attacks often have an anti-Semitic tinge; George Soros, widely reviled by right-wing populists throughout the region, is often denounced via standard anti-Semitic tropes about "Jewish bankers" and "rootless cosmopolitans"). Our symposium on The Hungarian Patient raises issues of interest to all scholars who care about academic freedom and the future of independent scholarship in Europe and beyond. I note with special pleasure the contributions of two Hungarian intellectuals who have been at the forefront of the struggle for democratization since the Communist period: Miklos Haraszsti, whose 1987 book The Velvet Prison was a major contribution to the East European literature of anti-communist dissent; and Agnes Heller, the former student of Gyorgy Lukacs, who was one of the leaders of the so-called "Budapest School" of Marxist humanism, and author, along with Ferenc Feher and Gyorgy Marcus, of the important dissident work Dictatorship Over Needs: An Analysis of Soviet-Type Societies, first published, in exile, in 1983.

Viktor Orban has been quite explicit in his rejection of "the Western model" of democracy, most notably in a widely-cited July 2014 speech at Băile Tuşnad, a Hungarian town in Romania: "the defining aspect of today's world can be articulated as a race to figure out a way of organizing communities, a state that is most capable of making a nation competitive. This is why ... a trending topic in thinking is understanding systems that are not Western, not liberal, not liberal democracies, maybe not even democracies, and yet making nations successful. Today, the stars of international analyses are Singapore,
China, India, Turkey, Russia. And I believe that our political community rightly anticipated this challenge .... We are searching for (and we are doing our best to find, ways of parting with Western European dogmas, making ourselves independent from them) the form of organizing a community, that is capable of making us competitive in this great world-race... In order to be able to do this in 2010 , and especially these days, we needed to courageously state a sentence, a sentence that, similar to the ones enumerated here, was considered to be a sacrilege in the liberal world order. We needed to state that a democracy is not necessarily liberal. Just because something is not liberal, it still can be a democracy... The Hungarian nation is not a simple sum of individuals, but a community that needs to be organized, strengthened and developed, and in this sense, the new state that we are building is an illiberal state, a non-liberal state."

In announcing this commitment Orban was doing much more than making a claim about the (il)legitimacy of liberal democratic regimes. He was denouncing "the West," and aligning himself with a new geopolitical tendency centered on illiberal and strongly nationalist states-Singapore, China, India, Turkey, and especially Russia.

Indeed, in the same way that the Bolshevik Revolution of October 1917 dramatically affected global politics, current developments and contests associated with "post-communism" have major implications for world politics today.

One major development of great consequence is the rise to global power of China, powered by a unique combination of capitalist economics and Communist party domination. This development is discussed in many of the book reviews in our special section, and is the focus of Jessica Chen-Weiss's important review essay, "Thinking About China and the Future of World Politics."

A second development, more central to this issue of Perspectives, is the reassertion of geopolitical power by Russia under the leadership (or domination; you decide) of Vladimir Putin. This issue contains three important pieces on this topic. Nicole Weygandt and Peter Katzenstein's "Mapping Eurasia in an Open World: How the Insularity of Russia's Geopolitical and Civilizational Approaches Limits its Foreign Policies" represents an extension of Katzenstein's important approach to "world civilizations," which runs directly counter to Samuel Huntington's "clash of civilizations," though it is carefully attuned to the ways that "civilizations" can be mobilized for the purposes of international and transnational conflict (Katzenstein's 2009 APSA Presidential Address was the first Address published under my editorship, in March 2010, under the prescient title "Walls' between 'Those People'? Contrasting Perspectives on World Politics"). Weygandt and Katzenstein are interested in the rise of "Eurasianism" as a civilizational discourse and a geopolitical 
organization of power. They pay particular attention to the geopolitical ideas of Aleksandr Dugin, the Russian academic who apparently has the ear of Putin (and is also frequently cited as an influence on the "thinking" of Donald Trump's "chief counselor," Steve Bannon). They discuss how a confluence of Russian interests and themes come together under the banner of "Eurasianism" and how this ideology essentializes civilizational conflicts and rationalizes Russian authoritarianism at home and expansion abroad (they discuss the war with and inside Ukraine and "frozen conflicts" in other ethnic regions in Eurasia, including in Moldova's Transnistria region, South Ossetia and Abkhazia in Georgia, and Nagorno Karabakh in Azerbaijan). And they situate "Eurasianism" at this moment of world history: "Much like the Russian revolution and the rise of Eurasianism in the 1920s, the disintegration of the Soviet Union in 1991 acted as a trauma that gave rise to new versions of Eurasianism. Both traumas elicited a strong anti-Western response. In the 1920s Eurasianist thinkers reacted against Western Socialism, in the 1990s against Western Neoliberalism."

Andreas Umland's "Post-Soviet Neo-Eurasianism, the Putin System, and the Contemporary European Extreme Right" develops similar themes, reviewing four recent books on Eurasianism. Umland argues that Eurasianism has become an increasingly important source of legitimation for Putin's regime: "to the degree that Putin's government is, because of various economic factors, losing its earlier performance-based legitimacy, it is increasingly turning to charismatic and ideological forms of self-legitimation. At this point, Russia's rich tradition of illiberal nationalist thought enters the stage. Although it plays, so far, an instrumental rather fundamental role for the 'Putin System,' elements of right radical rhetoric-i.e. conspiracy theories, leader-cult, anti-Americanism, messianism, nativism, irredentism, clericalism, homophobia, fortress-mentality, lawand-order slogans etc.- - have become part and parcel of Russian official statements, foreign policies and public discourse. Arguably, they are starting to assume a life of their own." Umland also devotes substantial attention to the non-Russian sources of current versions of Eurasianism, which represents a "hybrid, drawing primarily on nineteenth-and early twentieth-century mystical geopolitics, the German Conservative Revolution, European NationalBolshevism, British Satanism, the French New Right, Italian neo-Fascism, Integral Traditionalism, and some other nonRussian radical intellectual as well as political movements." Umland also notes the strong connections between Dugin and such leaders of the European "New Right" as Alain de Benoist in France and Robert Steukers in Belgium.

Joanna Szostek's "The Power and Limits of Russia's Strategic Narrative in Ukraine: The Role of Linkage" addresses another dimension of Russian power in world politics-communicative power. As she notes: "After the Ukrainian president was toppled by protests in 2014, most
Western governments and Ukraine's new leadership narrated the events in terms of a pro-democracy revolution against the corrupt ancien regime. They narrated Russia's subsequent annexation of Crimea and backing for separatists in Donbas as illegal actions by an irresponsible aggressor. In stark contrast, the Russian government projected a narrative in which the Ukrainian president's ousting was an illegitimate Western-backed coup, while its own policies vis-à-vis Crimea and Donbas were based on humanitarian need and historical justice. These conflicting and still evolving 'anti-Russian' ('pro-Western') and 'antiWestern' ('pro-Russian') narratives are both accessible to Ukrainian audiences." Centering her attention on Ukrainian audience reception of Russian media messages, Szostek argues that "support for the strategic narrative of a foreign government is more likely when there is social and communicative linkage at the individual level, i.e. when an individual maintains personal and cultural connections to the foreign state through regular travel, media consumption, religious attendance and conversations with friends or relatives. The role of linkage is demonstrated in Ukraine, where a 'pro-Russian, anti-Western' narrative projected from Moscow has been competing against a 'pro-Western, anti-Russian' narrative projected from Kyiv. Previous accounts of international persuasion have been framed in terms of a state's resources producing advantageous 'soft power.' However, this article proposes a shift in focus: from the resources states have to what individuals do to maintain social and communicative ties via which ideas cross borders."

The Ukrainian conflict-at once geopolitical, political, and ideological—neatly segues to another concern closely linked to the theme of "post-communism:" the theme of "Europe" itself, as a geographic space, as a political association, and as an idea. As readers of this journal well know, the meaning and the very future of Europe is very much in question at present. And while the geopoliticalcum-ideological developments associated with Putin's "Eurasianism" and the tendency of illiberal leaders such as Orban to lean eastward is one source of this, a more profound source of challenge is the crisis of European capitalism, precipitated by the 2008 financial crisis, which has pushed the Eurozone, and perhaps the EU itself, to the breaking point. Our symposium on Mark Blyth's Austerity: The History of a Dangerous Idea centers on the ideological roots of the current political-economic crisis (a forthcoming review of Cornel Ban's Ruling Ideas: How Global Neoliberalism Goes Local also develops this theme), and features Sarah Binder, Glyn Morgan, and Thomas Oatley. Our symposium on Lawrence R. Jacobs and Desmond King's Fed Power: How Finance Wins also features this theme, and includes comments by Jacqui True, Fred Block, Leo Panitch, and Elisabeth Prügl. And our symposium on Aida H. Hozic and Jacqui True's anthology, Scandalous Economics: Gender and the Politics of Financial Crises, centers on the important ways that the 
politics of austerity is gendered-a topic too-often ignored in standard accounts—and features Oana Băluţă, Daniel Drezner, Dara Strolovitch, and Laurel Weldon.

Samuel Brazys and Aidan Regan present a case study of the politics of austerity in their "The Politics of Capitalist Diversity in Europe: Explaining Ireland's Divergent Recovery from the Eurozone Crisis." They proceed from the fact that Ireland is often portrayed as a "success story" for its recovery from the 2008 financial crisis, in contrast to Southern European states like Greece, Portugal, and Spain, who are said to have been resistant to austerity politics. Brazys and Regan argue that "Ireland's economic recovery has little, if anything, to do with austerity-induced cost competitiveness. Rather it is the outcome of an activist state-led enterprise policy aimed at 'picking winners" from Silicon Valley.' ... The important question, then, is how did the Irish state develop the conditions for the emergence of this FDI-led growth regime in a period of austerity and contracting domestic demand, while the rest of the Euro periphery could not?" After outlining Irish enterprise policy in careful detail, Brazys and Regan draw some lessons from their account: "the neoliberal attempt to impose a one-size-fits-all adjustment on heterogeneous political economies in the $\mathrm{EU}$ is only likely to exacerbate the growing crisis of 'democracy without choice' in Europe.... European policymakers would do well to acknowledge the core inference from the study of comparative capitalism, which is that there are multiple pathways to economic and employment growth, and that the attempt to impose a one-size-fits-all adjustment on institutionally diverse political economies is only likely to exacerbate the growing political and economic divergence between the north and south of Europe. Unless member-states are given the political and fiscal flexibility to pursue their own economic and employment growth paths, then the future of the EU may well be a politics of disintegration."

The future of the EU is receiving much attention by political scientists, as Vivien Ann Schmidt makes clear in her review essay, "Where is the European Union Today? Will it Survive? Can it Thrive?" It is also the focus of Peter Verovšek's "The Immanent Potential of Economic and Monetary Integration: A Critical Reading of the Eurozone Crisis." While Brazys and Regan approach the crisis through the lens of comparative political economy, Verovšek argues that the dynamics of the EU crisis underscore "the need for bridging empirical and normative analysis." Verovšek is interested primarily in the legitimacy crisis of the EU, which is plagued by both a "democratic deficit" and an inability to deal effectively with the sometimes dramatic political-economic differences between member nations. He proceeds via a critical discussion of the European debate that pits supporters of greater national sovereignty such as Pierre Manent and Wolfgang Streeck against supporters of a stronger and more institutionalized form of democratic European legitimacy such as Jurgen Habermas. Verovšek leans towards the
Habermasian view: "the Eurozone contains the internal normative principles necessary to support greater political integration. While the citizens of Europe must provide the democratic legitimation necessary to realize this latent potential, the flaws revealed by the crisis are already pushing Europe towards greater transnational solidarity ... I argue that the peoples of Europe must further their 'experiment with new forms of governance outside the nation-state' in order to effectively confront powerful international markets that have been able to dictate the policies of sovereign states by demanding ever larger interest rates on government bonds. In order to do so the citizens of the EU will have to reassert their democratic authority vis-à-vis supranational and national elites, as well as international economic actors."

As a number of the contributions to this issue of Perspectives make clear, these challenges of geopolitical order, political-economic regulation, and transnational governance pose fundamental questions not simply about the future of Europe but also about the fate of liberal democracy itself.

Ronald Inglehart and Pippa Norris's "Trump and the Populist Authoritarian Parties: The Silent Revolution in Reverse" tackles this issue head-on, revisiting Inglehart's famous "postmaterialist values" thesis (in his 1977 The Silent Revolution) in light of the contemporary rise of "populist authoritarianism" in France, Germany, the United Kingdom (via the Brexit vote) and the United States itself with the election of Donald Trump. As they write: "While the Silent Revolution thesis explored the implications of the high prosperity and advanced welfare states that prevailed in high-income countries during the postwar era, in this piece we reflect on the implications of recent backlashes against postmaterialism." They state their core argument clearly: "Postmaterialism eventually became its own grave-digger. From the start, the emergence of pervasive cultural changes provoked a reaction among older and less secure strata who felt threatened by the erosion of familiar traditional values. A Materialist reaction against these changes led to the emergence of xenophobic populist authoritarian parties such as France's National Front. This brought declining social class voting, undermining the working-class-oriented Left parties that had implemented redistributive policies for most of the 20th century. Moreover, the new non-economic issues introduced by Postmaterialists overshadowed the classic Left-Right economic issues, drawing attention away from redistribution to cultural issues, further paving the way for rising inequality."

Katherine J. Cramer develops similar themes in her book The Politics of Resentment: Rural Consciousness in Wisconsin and the Rise of Scott Walker. The book has received extraordinary attention in the wake of Trump's November 2016 election, and it is the topic of a major symposium in this issue, with contributions by Edward G. Carmines and Eric R. Schmidt, Darren Davis, Jeffrey 
Dudas, Roger Petersen, Deborah Schildkraut, and Christina Wolbrecht. Jan-Werner Muller's What is Populism?, reviewed by Turkuler Isiksel, and Laura Grattan's Populism's Power: Radical Grassroots Democracy in America, reviewed by Thea Riofrancos, have also received substantial attention for their accounts of the current ascendancy of populism.

One of the hallmarks of this populism is a suspicion of and hostility towards all procedures and institutionspolitical parties, legislative assemblies, and "special interests" of all kinds - that supposedly obstruct the unvarnished "will of the people." In voicing such suspicion, contemporary populist leaders such as Trump, Marine Le Pen, Nigel Farange, Geert Wilders, and Viktor Orban are reviving a discourse that first rose to prominence a century ago, during the interwar period that saw the rise of left and right forms of totalitarianism. The rejection of a parliamentary republic was a central theme of the Bolshevik Revolution. Lenin, who frequently denounced the "parliamentary cretinism" of "bourgeois" legislative assemblies, emphatically linked his advocacy of "all power to the soviets" in his 1917 book The State and Revolution to the rejection of parliamentarism: "A $\mathrm{A}$ working, not a parliamentary body" - this is a blow straight from the shoulder at the present-day parliamentarian country, from America to Switzerland, from France to Britain, Norway and so forth-in these countries the real business of 'state' is performed behind the scenes and is carried on by the departments, chancelleries, and General Staffs. Parliament is given up to talk for the special purpose of fooling the 'common people." A similar sentiment, expressed even more militantly, and with a strong dose of antisemitism, can be found in Hitler's 1925 Mein Kampf: "All the parties that profess so-called bourgeois principles look upon political life as in reality a struggle for seats in Parliament. The moment their principles and convictions are of no further use in that struggle they are thrown overboard, as if they were sand ballast. . . They lack the great magnetic force which alone attracts the broad masses; for these masses always respond to the compelling force which emanates from absolute faith in the ideas put forward, combined with an indomitable zest to fight for and defend them. Our present movement is accused ... of heading towards a revolution. We have one answer to give to those political pigmies. We say to them: We are trying to make up for that which you, in your criminal stupidity, have failed to carry out. By your parliamentarian jobbing you have helped to drag the nation into ruin. But we, by our aggressive policy, are setting up a new philosophy of life which we shall defend with indomitable devotion. Thus we are building the steps on which our nation once again may ascend to the temple of freedom. And so during the first stages of founding our movement we had to take special care that our militant group which fought for the establishment of a new and exalted political faith should not degenerate into a society for the promotion of parliamentarian interests."
Indeed, the commonality between left and right critiques of parliamentarism during this period was central to the argument of famed German jurist and Nazi-sympathizer Carl Schmitt in his 1923 The Crisis of Parliamentary Democracy. Authentic democracy, he insists, is not about legality or proceduralism or the protection of fundamental political rights; it is about "the will of the people," and of the possibility of this will being manifested, without mediation and beyond doubt, by political leadership. Such a system is anti-liberal, and attains its legitimacy from something more profound than a politics of vigorous political debate and electoral competition for votes: "The will of the people can be expressed just as well and perhaps better through acclamation ... than through the statistical apparatus that has been constructed with such meticulousness in the last fifty years. The stronger the power of democratic feeling, the more certain is the awareness that democracy is something other than a registration system for secret ballots. Compared to a democracy that is direct, not only in the technical sense but also in a vital sense, parliament appears as an artificial machinery, produced by liberal reasoning, while dictatorial and Caesaristic methods not only can produce the acclamation of the people but can also be a direct expression of democratic substance and power."

For Schmitt, it is precisely such "substance and power" that defines authentic democracy and whose absence marks liberal democracy as inauthentic and weak. This liberal democratic weakness is epitomized by the idea that the purpose of law is to protect certain basic human rights as such. Schmitt insists that this idea is specious, enervating (emasculating?) and hostile to democracy: "A democracy demonstrates its political power by knowing how to refuse or keep at bay something foreign and unequal that threatens its homogeneity." And this is why he argues that both Bolshevism and Fascism represent authentic versions of democracy - for both are animated by a struggle to exclude and to defeat something that is "foreign" and threatening to "homogeneity." In the case of Bolshevism, the enemy is a "class enemy" defined in a "rationalist" way. In the case of Fascism, the enemy is an ethnic or "racial enemy" defined in an "irrationalist" way. But while these two forms of democracy rest on different "substantial" foundations, both are authentically democratic - and worthy of real contestbecause both are energized by the need to exclude and to fight "enemies of the people."

As I write this, in late February 2017, the Trump administration is in its sixth week. President Trump's inaugural speech presented an image of an America weak, corrupt, and prostrate in the face of enemies foreign and domestic. "This American carnage stops right here and stops right now," he declared. He then announced that his inauguration would be declared "A National Day of Patriotic Devotion": "A new national pride stirs the American soul and inspires the American heart. We are 
one people, united by a common destiny and a shared purpose." As a number of commentators noted, the rhetoric of both his speech and his declaration do more than articulate a general commitment to civic values; they articulate the idea that his ascendancy to power represents a special historical moment, that he alone has the pulse of the people and is empowered to rescue a nation on the brink of collapse ("this American carnage ..."). This is the message that he has delivered ever since his July 2016 acceptance of the Republican party nomination, where he announced that "Every day I wake up determined to deliver for the people ... that have been neglected, ignored, and abandoned ... the forgotten men and women of our country. People who work hard but no longer have a voice. I AM YOUR VOICE ... I have joined the political arena so that the powerful can no longer beat up on people that cannot defend themselves. Nobody knows the system better than me, which is why I alone can fix it." This posture, as a tribune of the common people and a scourge of all "elites," has been propelled in large part through a rhetorical war against all critics and especially the independent press, who Trump has consistently decried as "liars," "evil," purveyors of "fake news," and most notably as "enemies of the people" who he intends to bring to heel.

Many commentators across the spectrum-politicians, journalists, and scholars - have noted the "dictatorial" affinities of this rhetoric. These are no doubt complicated issues. At the same time, it is notable when prominent conservative Republicans raise these issues. Senator John McCain quite publicly has distanced himself from the Trump rhetoric: "We need a free press. We must have it. It's vital. If you want to preserve-I'm very serious now-if you want to preserve democracy as we know it, you have to have a free and many times adversarial press. And without it, I am afraid that we would lose so much of our individual liberties over time. That's how dictators get started." Even more notable is the response of conservative talk show host Joe Scarborough, a former Republican Congressman elected during the socalled "Gingrich Revolution" of 1994 who has often furnished Trump with a platform on his show. Scarborough immediately responded to Trump's first invocation of "enemies of the people" line with this Tweet: "This president attacks the judiciary's legitimacy, the intel community, and calls press outlets critical to him 'the enemy of the people.' Conservatives, feel free to speak up for the Constitution anytime the mood strikes. It is time." On his show he went further, saying that this rhetoric is "straight out of a Mussolini playbook."

Whether it is Mussolini, or Schmitt, or the widelyremarked resurgence of the "alt-right" linked to Breitbart, or the elevation of Stephen Bannon to chief White House Counselor, or Bannon's very public admiration for both the Italian fascist philosopher Julius Evola and Lenin himself ("I'm a Leninist ... Lenin wanted to destroy the state, and that's my goal, too.... I want to bring everything crashing down, and destroy all of today's establishment," he is widely quoted as having said)—we are currently witnessing the resurgence of many of the same ideas and tendencies that led in the 1930's and 1940's to what Juan Linz and Alfred Stepan called, in their classic 1978 work, The Breakdown of Democratic Regimes.

Perhaps it is worth closing as I began, with Rosa Luxemburg, the revolutionary Marxist whose 1919 assassination turned her into a martyr of the socialist left and a hero of radical democrats. Correctly foreseeing the barbarism of WWI, she hoped for, and then enthusiastically embraced, the upsurge of revolutionary radicalism of 1917. But within a year of the Bolshevik seizure of power in Russia, she had become deeply concerned and profoundly disenchanted by the course of the Revolution. In 1918, while still in prison, she penned her famous pamphlet "The Russian Revolution." Here too she was prescient, in her critique of the Bolsheviks but also in her more general critique of authoritarianism of any kind: "Freedom only for the supporters of the government, only for the members of one party-however numerous they may be-is no freedom at all. Freedom is always and exclusively freedom for the one who thinks differently. Not because of any fanatical concept of 'justice' but because all that is instructive, wholesome and purifying in political freedom depends on this essential characteristic, and its effectiveness vanishes when 'freedom' becomes a special privilege.... The negative, the tearing down, can be decreed; the building up, the positive, cannot. New Territory. A thousand problems. Only experience is capable of correcting and opening new ways. Only unobstructed, effervescing life falls into a thousand new forms and improvisations, brings to light creative new force, itself corrects all mistaken attempts. The public life of countries with limited freedom is so poverty-stricken, so miserable, so rigid, so unfruitful, precisely because, through the exclusion of democracy, it cuts off the living sources of all spiritual riches and progress." Luxemburg insisted that "Without general elections, without unrestricted freedom of press and assembly, without a free struggle of opinion, life dies out in every public institution." Such an eventuality could only mean corruption, impoverishment, political repression, and "the brutalization of public life."

As we near the end of the second decade of the $21^{\text {st }}$ century, we face many of the same challenges faced a century ago by our forbears. Like them, we are challenged to understand momentous developments unfolding in real time, and also to figure out whether and how we, as bearers of a sense of intellectual responsibility, can contribute meaningfully to a public life increasingly beset by resentment and fear and engulfed in darkness. As Luxemburg stated, "Only experience is capable of correcting and opening new ways." Are we capable of taking the proper measure of the past century of politics, and of acting accordingly? 


\title{
The Centrality of Books to Political Science and to Perspectives on Politics
}

\author{
By Jeffrey C. Isaac, Editor in Chief
}

Almost half of every issue of Perspectives is dedicated to our Review section. This structure of the journal is something that we inherited, for when Perspectives was created, it was decided to move the APSA book reviews, which had previously been published in the APSR, to Perspectives, and to open up the new journal to a range of writing formats.

We inherited this structure, but we also embraced it.

Indeed, I assumed the position of Editor in Chief of the entire journal after having served for four years as the Book Review Editor under the editorship of my predecessor, Jim Johnson. During my tenure as Book Review Editor we made a conscious decision to innovate with this section, by creating new formats-Critical Dialogues, Book Symposia, different kinds of thematic review essays, and Review Editor Introductions highlighting common themes - and trying to make the "back end" of Perspectives a space for lively conversation across conventional subfield and methodological divides in the discipline. These innovations were announced and explained in my inaugural editorial statement, "A Statement from the Book Review Editor" (Perspectives on Politics, March 2006, pp. 3 4 ), and the approach to the journal's treatment of books has remained true to the perspective outlined in that public text.

When I was offered the editorship of the entire journal in 2009, I agreed to accept this position on the basis of a clearly defined vision that was grounded in our experience with the Review section, and I was committed to editing the entire journal as a whole. My reason was straightforward: I believed that the journal was a unique and precious intellectual resource, and I was-and am-deeply committed to placing it on the strongest possible footing as a venue that features a wide range of political science perspectives and formats in a genuinely integrated way. It is surely possible for the two "ends" of the journal to be edited by separate individuals, working together in a collaborative fashion. But I was and am strongly committed to the idea that the two ends can and should be integrated into a single whole; that each "end" should in fact have diverse formats, so that in fact the journal would be much more complicated and interesting than a simplistic oppo- sition of "articles" and "reviews" implies; and that these formats should speak to one another.

This vision was endorsed by the APSA officials - the search committee chaired by Rogers Smith, APSA President Peter Katzenstein, and the APSA Council-who unanimously supported my appointment.

When my editorial team took over the entire journal in 2009, we "branded" the journal as "A Political Science Public Sphere," and worked hard to nurture synergies between the research articles and essays published in the journal's "front end" and the reviews and book discussions published in its "back end" (this vision was announced in "Perspectives on Politics: A Political Science Public Sphere," my editorial statement published in the March 2010 issue, and now printed at the beginning of each issue). My staff and I have devoted enormous energy to this approach to the journal, with the strong support of our dedicated Editorial Board and with the support of the APSA Council. These efforts were recognized by the 2011 Performance Review Committee that recommended the extension of our editorial tenure. But in my view the most important "recognition" of this approach is the fact that we continue to enjoy the enthusiastic participation of many hundreds of authors and reviewers every year, and to produce a publication that includes a wide range of excellent contributions across a range of formats.

At the heart of the journal as it has come to be structured, read, and appreciated within the profession, is the deliberate effort of our editorial team to discern, nurture, and publicize complementarities, synergies, and broad thematic interests that might otherwise be insufficiently recognized by our increasingly specialized academic life. Our entire range of formats is dedicated to this end. We have nurtured the production of research articles that are rigorous, rigorously peer-reviewed, and at the same time are written and framed more broadly than conventional research articles. We have nurtured a range of conversations about political science books, and promoted conversations between our articles and our book reviews and essays. These connections have been essential to our vision of "a political science public sphere." 
Readers of the journal will be familiar with this range of formats, and with their complementarities:

- Research articles

- "Reflections" essays

- Book Review Essays

- Book Symposia

- Book Critical Dialogues

- "Undisciplined" Reviews and Review Essays (featuring reviews of books from other disciplines)

- A special thematic Book Review section in each issue

- Standard single, double, and triple Book Reviews

Readers will also be familiar with the ways that we have sought to plan our production schedule so we can package writings in these formats together thematically, and highlight these themes in my Editor Introductions. These efforts draw scholarly and public attention to broad and interesting themes. And by promoting broad and relevant scholarly discussion, they also help us reach beyond the discipline, and to gain the attention, and sometimes even the involvement, of journalists, policy intellectuals, and sometimes even a broader reading public. Recent examples include:

- Our June 2012 issue featuring work on violence

- Our September 2012 special $10^{\text {th }}$ Anniversary issue on "Post-Katrina New Orleans and the Politics of Reconstruction"

- Our March 2013 issue featuring work on "The Politics of Inequality in the Face of Financial Crisis"

- Our June 2013 issue featuring work on "Nature and Politics"

It is sometimes overlooked how central our Book Review section is to these efforts. But even a casual perusal of any recent issue of Perspectives will remind colleagues of the centrality of books.

I have been a professional political scientist for over thirty years. We are all well acquainted with the still widely accepted notion that book review assignments are convenient means of getting a free book that you want to read and of dashing off a thousand-word commentary during one's breaks from "real" research and writing. For the past eight years we have worked tirelessly, and successfully, to counter this unfortunate notion.

Books are important, and so serious intellectual attention to them is important.

While promptly published scholarly articles are also important, the book format remains the only format that allows scholars, in every field and from every perspective, to take the time and space to develop an argument in depth. Books are at the heart of political science. Important books help to create new research agendas. The names Almond or Dahl or Katzenstein or Putnam or Skocpol or Ostrom or Riker or Olson or Fenno or Mansbridge or Aldrich do not evoke journal articles. Each evokes an important book, and typically more than one of them. Every year many hundreds of new political science books containing new political science perspectives are published. We know this. The Book Exhibit at the annual APSA conference is one of the main attractions for almost everyone.

These books seek and deserve more than mere citation and more than glorified "Book Note" type reviews. They deserve serious discussion in a serious scholarly context. They deserve well-written reviews that are carefully edited by editors who work with reviewers, and prompt them to think a bit more broadly, and to view their book reviews as real scholarly engagements. Such reviews do much more than publicize and provide short cuts to books that readers might not otherwise know about. They engage the books and make them really a part of serious scholarly dialogue.

But there is something else: these reviews make their authors part of seriously scholarly dialogue.

Most of our colleagues do not work at research-intensive universities. Most of them spend most of their time teaching, often with heavy loads, either as tenured or tenuretrack professors at teaching institutions, or as adjuncts and part-time academic workers. For many of our colleagues, the chance to write a fine book review, and to have it seriously engaged by an editor, and to have it published in a "flagship research journal," is one of the only significant opportunities they may have to write and to publish in a given year.

Every year Perspectives on Politics publishes hundreds of book reviews written by a very wide range of scholars with a wide range of institutional affiliations. We are very serious about the range and diversity of the contributors to our book review section. One reason is because it allows our journal to reach broadly, and to include many of readers as contributors. This "community-building" function of Perspectives is very important, for a scholarly community ought to be linked by scholarly conversation in which each participant has genuine opportunities to speak as well as to listen and to be an author as well as a reader.

But this kind of inclusion is also important in an epistemic sense. For it "enforces" a breadth of scholarly perspective, and brings expert discourses into conversation with more generalist perspectives, to the benefit of the kind of true critical engagement that is the heart of the scientific enterprise. In this sense, every 1500 word book review that we publish is much more than a professional "service"; it is a serious contribution to scholarship and to the development of scholarly research. And the publication of these reviews in a flagship journal of political science, alongside rigorously peer reviewed research articles, essays, symposia, and dialogues, highlights their importance.

We are excited about the range of formats contained within Perspectives, and the way that they work together to project a vision of scholarly and intellectual seriousness. We believe that in this age of specialization, "modularity," 
and almost costless digital creation and circulation of texts, it is important for an intellectually serious political science discipline to have at least one broad, integrated, and intellectually serious journal that features a range of perspectives, formats, and scholars.

We believe, in short, that it is important for there to be a political science public sphere.
We are also grateful to the many colleagues who support us in these efforts, and who embrace the chance to be active participants in and contributors to the journal and its many formats. We continue to receive a growing number of article submissions, and we have many exciting book review special features planned in the coming issues. As we move forward, we welcome your ideas and suggestions. 